This item was submitted to Loughborough's Research Repository by the author.

Items in Figshare are protected by copyright, with all rights reserved, unless otherwise indicated.

\title{
Cold War binaries and the culture of consumption in the late Soviet home
}

\section{PLEASE CITE THE PUBLISHED VERSION}

http://dx.doi.org/10.1108/JHRM-09-2015-0038

\section{PUBLISHER}

(c) Emerald

\section{VERSION}

AM (Accepted Manuscript)

\section{PUBLISHER STATEMENT}

This work is made available according to the conditions of the Creative Commons Attribution-NonCommercialNoDerivatives 4.0 International (CC BY-NC-ND 4.0) licence. Full details of this licence are available at: https://creativecommons.org/licenses/by-nc-nd/4.0/

\section{LICENCE}

CC BY-NC-ND 4.0

\section{REPOSITORY RECORD}

Reid, Susan. 2016. "Cold War Binaries and the Culture of Consumption in the Late Soviet Home". Loughborough University. https://hdl.handle.net/2134/19261. 


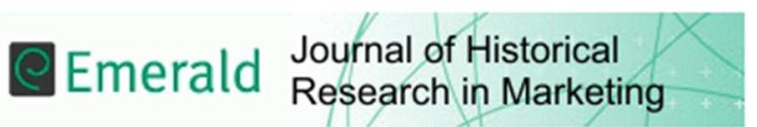

\section{Cold War Binaries and the Culture of Consumption in the Late Soviet Home}

\begin{tabular}{|r|l|}
\hline Journal: & Journal of Historical Research in Marketing \\
\hline Manuscript ID & Draft \\
\hline Manuscript Type: & Research Paper \\
\hline Keywords: & $\begin{array}{l}\text { Consumption history, Consumer culture, Cold War, Soviet Union, mass } \\
\text { housing, Khrushchev }\end{array}$ \\
\hline \multicolumn{2}{|l}{} \\
\hline
\end{tabular}

SCHOLARONE ${ }^{m}$

Manuscripts 
Cold War Binaries and the Culture of Consumption in the Late Soviet Home

"The Kremlin has made concessions to consumers, but Russia is far from being a consumer society," reported New York Times Moscow correspondent Hedrick Smith in his 1976 book The Russians (Smith, 1976, p. 105). His doubts notwithstanding, Smith dedicated a chapter to Soviet consumption. Its title juxtaposed two seemingly incompatible concepts: "Consumers: the Art of Queuing". Thereby Smith followed a Cold War convention that still underpins retrospective accounts today: if western commentators acknowledged Eastern Bloc consumption as a legitimate object of study at all, they characterized it in terms of paradox, associating it with sacrifice, austerity, and scarcity, and with patient, passive waiting for goods. While western consumer culture was synonymous with superfluity, indulgence and redundancy of consumer choice, the USSR and its satellites were described as "societies of shortage" that were structured by "dictatorship over needs." Relations with goods were defined by necessity rather than choice, desire, image and semiosis; by nature rather than culture; and by central command rather than decentralized demand (Kornai, 1980; Fehér et al., 1984; Shlapentokh, 1989; Hessler, 1996; Merkel, 1999; Landsman, 2005). Based on "an elementary level of provisioning that departed dramatically from consumption in a modern sense" (Merkel 2008), this state socialist "command consumption" represented, for good or bad, the antithesis of the paradigmatic consumer culture or consumerism of the West, which "assumes a society that is driven and mobilized by marketing and corporate strategies that stimulate and then fulfill ever more unquenchable desires" (Bren and Neuburger, 2012, p. 5; Reid, 2002). These might even be called anti-consumer societies or, at best, belated (Merl, 1997) or not-yet-consumer societies in which, as Smith wrote, consumption was a concession to boost production rather than a defining aspect of socialist modernity.

During the Cold War, scholarly treatments of Soviet consumption, consumer culture and marketing were rare exceptions (Goldman, 1963, 1968; Hanson 1968, 1974; Shapiro, 1980; Skurski, 1983). Consumption was recognized retrospectively as a key issue for understanding the societies of the USSR and former Eastern Bloc after the collapse of state socialism and subsequent emergence of neoliberal regimes and consumerist cultures there. These developments generated new questions about the socialist past in search for explanations for the present (e.g. Verdery, 1996; Veenis, 1997; Steiner, 1998; Merkel, 1998, 1999; Reid and Crowley, 2000; Siegelbaum, 2008). As a result, the meaning and effects of socialist consumption have sometimes been understood teleologically, in terms of the decline and collapse we know came later, thereby reinforcing the equation of modernity with triumphant liberal capitalism and 
perpetuating rather than challenging the Cold War binary image of advanced consumerist West v. backward anti-consumerist East (Pence and Betts, 2008, p. 7; Reid, 2008). A prevalent explanation offered for the collapse in the late 1980s has been that state socialist regimes had raised expectations they could not satisfy so that Soviet-type socialism in Europe "fell victim to a growing gap between consumer aspirations and resources" (Verdery, 1996). This narrative dovetailed with ideological assumptions about the essential non-viability of a planned economy, according to which command systems were inherently unable to grow and were doomed to fail by comparison with market economies (Harrison, 2002). Not only the failures but even the successes of Soviet efforts to provide for consumption have been marshalled into arguments claiming that a "state socialist consumer society" was an impossibility or oxymoron, and noting the irony that "the Soviet regime's success in modernizing Soviet society promoted attitudes and values that tended to undermine it" (Millar and Wolchik, 1994b, pp. 2-3; Dobson, 1994, p. 230). If rising levels of consumption were recognized in the 1960s and 1970s, it was often assumed (both by western observers and, with different valuation, by internal guardians of socialist morality) that they presaged the system's decline and decay. Whereas, in the USA, good citizenship was identified with being a consumer, and the nation's economic success and indeed, its identity, were dependent on mass consumption (Cohen, 2003), regarding the USSR, consumption, and especially consumerism, were assumed to be a potentially corrosive force. They threatened to destroy the Soviet edifice from within, leeching morale and ideological zeal, replacing collectivism by individualism, appealing to self-interest and avarice, and eroding shared values and social cohesion. Improvements in living standards and access to consumer goods threatened to undermine the socialist project because "modern consumption" was inherently incompatible with socialism, which traditionally identified itself with asceticism, eschewing commodity fetishism, status consumption, covetousness, and acquisitiveness (Millar, 1985; Millar and Wolchik, 1994b, p. 3; Shlapentokh, 1989, p. 2, pp. 223-25; Brown, 2013, pp. 259-60).

This paper seeks out the changing experience and meanings of consumption and consumer goods in citizens' everyday lives in the last Soviet decades. It will present evidence for qualitative changes in popular consumer culture, proposing that the social meanings and practices of consumption were in flux and contention in the late Soviet decades, a period of intensive modernization and rapid transformation in the everyday material environment of Soviet citizens. The problem is how to conceptualize the trajectory of change in ways that do justice to historical subjects' experience without uncritically reproducing Cold War binaries, post-Cold War teleologies, and the 
normative status claimed by the postwar West (above all the USA) in defining modernity and its associated forms of consumption (Trentmann, 2004).

\section{$<$ INSERT FIGURE 1 HERE $>$}

While economic data and analysis can reveal trends in production and may also indicate consumption patterns, in order to probe popular experience and changing meanings we need to turn to more qualitative and subjective sources. The paper draws on an oral history interview project Everyday Aesthetics in the Modern Soviet Flat. Over seventy semi-structured interviews were conducted between 2004 and 2007 with informants in a range of former Soviet cities: Leningrad (now St Petersburg), Kaluga, Samara, Kazan', Tartu (Estonia), and, in the Far North, Kovdor and the new city Apatity). As a criterion for inclusion in the project, all participants had been beneficiaries of the post-Stalin regime's mass-housing program begun in the late 1950s. The interviews were conducted in the interiors of the Khrushchev-era flats or "khrushchevki," where most participants still lived. The questions addressed the period during which my subjects first settled in and made home in these new flats, extending through the 1960s and 1970s, and they aimed to draw out their histories of homemaking and consumption for the home. This paper will focus on the acquisition of furniture for the new flats.

The participants in the interviews had in common the type of housing they inhabited, but they represented a diverse range of social strata, educational levels, occupations, and geographical locations. Some came from families that had belonged to the urban intelligentsia and propertied classes before the Revolution, and although purges and expropriation had stripped them of the material and social advantages of their class, some still demonstrated their hereditary cultural capital. Others were former kolkhoz (collective farm) peasants and first-generation urban dwellers and industrial workers. Almost all the informants were over sixty years old and retired, but they represented more than one generation, the oldest born in 1919, others in the mid-1940s. Although the sample is relatively small, its social diversity can help to test some received narratives, such as the assumption that consumption issues "led to" discontentment and anti-Soviet opinion (Bushnell, 1980; Shlapentokh, 1989). While this emphasis may partly be accounted for by the post-Soviet teleological search for explanations for the system's collapse, underpinned by Cold War ideological bias, it may also be explained by a tendency to focus on the views of the metropolitan intelligentsia and to seek out forces regarded as anti-Soviet or dissident. Analyzing the data of the Soviet Interview Project (SIP)--a study of Soviet citizens' attitudes conducted at Harvard in the early 1980s on the basis of interviews with recent Soviet emigrants to the USA--James Millar and 
Elizabeth Clayton found that those who had apparently benefited the most were the least contented. The young, the educated and the well-paid proved to be the most critical and least satisfied with life in the Soviet Union (Millar and Clayton, 1987, pp. 42$43,52-56)$. While my interview material does not unambiguously support this view-many of my intelligentsia informants seem among the most contented, including those who travelled abroad extensively and were thus exposed to other ways of life-it corroborates their point that the relation between material improvements and rising happiness is more complex.

\section{"We didn't build communism to sleep on a bed of nails"}

Shortage and unreliable supply undoubtedly played an important part in shaping people's behavior, attitudes, and material environments. However, the shortage paradigm has arguably outlived its usefulness and come to blinker accounts of Soviet consumer culture. To achieve a fuller understanding of the transformations that took place in the last Soviet decades and of how these were experienced by "ordinary" citizens, we should consider evidence for a different story, overlooked in the search for the causes of the Soviet Union's downfall. This is the story of the "contented years" of late state socialism (Brown, 2013, pp. 266-67), in which housing played an important part in securing the system's popular legitimacy and social stability (Millar and Clayton, 1987, pp. 39-42).

The post-Stalin decades were a period of rapid change in the material environment of everyday life. A seminal event in this new phase of accelerated urbanization and modernization was Nikita Khrushchev's launch, in 1957, of the intensive program of industrialized mass housing construction, thanks to which my interviewees, along with millions of other Soviet citizens, relocated to new apartments over the next decade. Aiming to solve the chronic shortage of housing through the use of standardization, prefabrication and industrialized construction methods, the program provided small, plain apartments with modern conveniences, designed for separate nuclear families rather than for communal occupation (DiMaio, 1974; Harris, 2012). The post-Stalin regime also undertook to raise mass living standards through a range of other measures including welfare, services, increased application of technology in the workplace and at home, and reductions in the working week. Consumer goods were granted greater priority in economic planning, and per capita consumption grew quite rapidly at first, although it slowed down in the early 1960s (Hanson, 1968). Further pro-consumer measures were introduced by Khrushchev's successors, Brezhnev and Kosygin. The Kosygin economic reforms, launched in September 1965, were first applied in the light 
industry sector, aiming to improve efficiency, quality and responsiveness. Raising the importance of material incentives, they implicitly required more and better consumer goods and services as the reward for increased productivity and efficiency. According to a September 1967 resolution, the growth rate for consumer goods was to outstrip that for other sectors, and the Ninth Five-Year Plan in 1971, for the first time, set the rate of growth for light industry and agriculture to exceed that for heavy industry (Schwartz, 1982, p. 109). Contemporary Western observers noted that the measures to raise living standards had begun to create "a climate of consumerism in which legitimate expectations for improved material well-being by the population kept increasing" (Schwartz, 1982, p. 109).

The mass process of making home in the new flats--experienced by a significant proportion of the Soviet population--played a pivotal role in the formation of what we might provisionally designate a "Soviet mass consumer society" and "modern consumer subjectivities." Before we can consider this proposition in more detail we need an operative definition of a consumer society, at the risk of imposing once again the normativity associated with the West's paradigmatic status. Historian Paul Glennie usefully summarized five characteristics of modern consumer societies: i. growing per capita consumption of commodities; ii. intensifying production and reorganized distribution systems; iii. increasing social divisions of labor and increasing social mobility (both symbolised by consumer goods); iv. growing individualism in social life; and v. consumer acquisitiveness tied to fashion and increasingly advertising (Glennie, 1995, p. 177). This last point is the one on which we will focus here, because it is the most related to the culture of consumption and often assumed to be (for good or bad) the prerogative of western capitalist modernity. In regard to the West, the specificity of modern consumer culture has been identified with mass consumption, and above all with capital's systematic manipulation of consumer knowledge through mass media advertising images. Modern consumer societies are distinguished by the role of images circulated with the express purpose of stimulating fantasy about possible selves and lifestyles and constructing needs (Campbell, 1987, 1995, pp. 103-4; Baudrillard, 2005).

While it is a commonplace that the Soviet Union made extensive use of mass media images to shape citizens' values, subjectivities and behavior, the role of media images, advertising, packaging and product design in promoting consumer mentalities under state socialism has received little attention. This is one of the ideological foreclosures produced by Cold War binary thinking, excluding the USSR from consideration as a "consumer society" (Kerblay, 1983, p. 284). If advertising, of a sort, was acknowledged, 
then it was presumed to promote ideology rather than goods and desires; it was "propaganda" rather than advertising or marketing (Barker, 1999, p. 7). Above all, as a shortage society, it was assumed, the USSR had little use for marketing, advertising or styling. Studies of these activities and the associated Soviet institutions have been correspondingly rare until recently (e.g. Hanson, 1974; Cox, 2003; Kiaer, 2005; Reid, 2013b).

Images of how and what to consume, produced by experts and widely disseminated in the media, were not, however, the monopoly of capitalist modernity. They were also central to normative constructions of identity and citizenship and the "new Soviet person." Campaigns for a new, socialist way of life and "socialist object" in the 1920s (Kiaer, 2005) were followed, in the 1930s, by the promotion of "cultured" consumption (Fitzpatrick, 1992; Hessler, 1996, 2000; Randall, 2008; Kelly and Volkov, 1998; Kravets, 2013). The role of image culture expanded in quantity and significance after Stalin, with increased mass reproduction of images and illustrated newspapers and popular magazines, a boom in cinema-going, and the entry of television into people's homes (Roth-Ey, 2011). This explosion of visual media took place in the context of the Soviet regime's increased emphasis on mass consumption, housing construction and modern urban living standards, and also in the international, Cold War climate of "Nylon Warfare" (Riesman, 1964; Reid, 2002, 2008). Images of consumption and improved living standards aimed to persuade both domestic and international audiences of the success of socialism, providing convincing evidence that the final transition to full communism-characterized, according to Khrushchev, by superabundance for all--was imminent (e.g. Khrushchev, 1959b; Izvestiia, 1959; Hodnett, 1974; Gilison, 1975).

\section{<INSERT FIGURE 2 HERE $>$}

In the West, "Ideal Homes" were a key site for the image culture of postwar consumerism. Model homes and representations thereof served as showcases for commodities, engendering desire not only for individual objects, but for the whole lifestyle they promised. They were also potent weapons in the Cold War living standards race; it was far from fortuitous that the planners of the American Exhibition in Moscow in 1959 chose the American home and kitchen as the site to wage "operation abundance" against the Soviet Union (Reid, 2008; Cohen, 2003; Castillo, 2010). But Soviet citizens were already being bombarded with images of Soviet "ideal homes" and of new consumer durables, furniture and electrical appliances to equip them. Popular illustrated magazines such as Ogonek, household manuals, exhibitions and television offered expert consumption "advice to the novosely" or "new settlers." Reporting on tales 
of "happy housewarming," they figured the ritual crossing of the threshold of the new home as the rebirth of the "new Soviet person" as a consumer (Reid, 2009). Aspiring "housewarmers," hopeful that they too would soon share in this joyful rite of passage, were encouraged to imagine a new modern lifestyle that would become theirs along with the keys to a new flat.

The mass circulation of images and texts did not simply appeal to existing needs and wants, but sought to reform popular taste and to restructure desire. They promoted an austere, modernist, "rational" style of interior decorating, dubbed the "contemporary style," to match the plain, functional architecture of the khrushchevki. New types of compact and multipurpose furniture and "contemporary style" designs suitable for mass industrial production began to be developed in the late 1950s (e.g. Blashkevich, 1957) and to be put into mass production in the early 1960s. Competitions for new designs were discussed and illustrated in the press, and prototypes were exhibited both to specialists and to the general public. A landmark exhibition, Art into Life in Moscow in 1961 presented new prototype furniture in model interior settings (Reid, 2006; TsAGM 21/1/125-130; RGALI 2329/4/139). These model interiors were disseminated virtually across the Soviet Union via television, magazines and advice books, in the form of photographs that made them look like actual interiors rather than exhibition mock-ups, as well as in brightly colored drawings in deft, modern graphic style (Baiar and Blashkevich, 1962; Peremyslov, 1962; Sharov and Poliachek, 1960; Voeikova, 1962; Nikol'skaia and Nikol'skii, 1963; Reid, 2006, 2010). The purpose of the 1961 exhibition was in part to consult the public on the designs before these went into mass production, but it also aimed to structure future demand in ways that could be fulfilled by mass industrial processes. The images and model interiors--untrammeled by the mess of everyday living in cramped quarters, emphasizing light, space, and unencumbered sightlines--encouraged viewers to project themselves imaginatively into the spaces of the new flats and into a lifestyle promoted as rational, tasteful, leisured, socialist and modern. They created a demand not simply for furniture "in general," to fulfil elementary needs, but for particular types and styles of furniture in accordance with the ideology of socialist modernity. Similar to the role of advertising in the West, the image preceded the actuality of the object itself; promotion of the contemporary style as a normal, legitimate aspiration, produced demand for new products well in advance of their becoming widely available and affordable, as is evidenced by the public's responses to Art into Life (TsAGM 21/1/125-130; RGALI 2329/4/139; Reid, 2006, pp. 265-7). Public discourse also identified the move to new flats with the development of new needs aside from furniture, normalizing entirely new categories of industrially 
produced goods: domestic appliances (Goldman, 1968). Both "time-using" appliances such as television, and "labor-saving" ones such as refrigerators and vacuum cleaners-were promoted as part of the modern Soviet lifestyle. The new "need" for appliances was produced by means similar to those used in the West: by the widespread circulation of images of appliances naturalizing them as part of an urbane modern, leisured, life style, and by associating them with women's emancipation from drudgery. The role of styling, advertising and packaging in producing and structuring demand was also paid greater attention in the 1960 s, as the Kosygin reforms made increased turnover more important to enterprises (Reid 2013b, pp. 44-6).

Even as images of consumption for the home promoted the legitimacy of state socialism, the situation was paradoxical, contradictory and in flux, creating dilemmas for ideologues and guardians of socialist morality. Khrushchev's promises of abundance for all were combined with his repeated condemnation of "excess" in regard to architecture but also to furniture (e.g. Khrushchev, 1959a, pp. 30-31). A range of intelligentsia experts admonished the public to consume "rationally," in moderation and with taste, eschewing un-Soviet, "petit bourgeois" excesses of consumption, acquisitiveness and commodity fetishism (Filonovich, 1959; Reid, 2002). Yet others, in the 1960s, began to reassess the traditional identification of socialism with asceticism. Influential philosopher of material culture Karl Kantor argued in 1961 that self-denial and disdain for material comfort, which had been required of revolutionary heroes in the past, were no longer necessary or appropriate in the present day; for, as young people legitimately objected, "We didn't build communism to sleep on a bed of nails like Rakhmetov" (GARF 9547/1/1311: 45), referring to the paradigm of the ascetic revolutionary, a character in Nikolai Chernyshevsky's 1863 novel What Is To Be Done? Economists also began to acknowledge that the norms of "rational consumption" were not fixed once and for all, but were dynamic and would grow along with the production capacity of the national economy (Reid, 2013b).

In the remainder of the paper, I will examine evidence for shifts, during the 1960s and 1970s, in the ways "ordinary" people chose and thought about furniture for the home. Along with quantitative growth, significant changes also began to take place in the nature and meanings of consumption, marking a watershed in the development of a Soviet mass consumer society, whereby they became not only purchasers and users of goods, but "modern" consumers of a sort, sharing some, though not all, of the characteristics of modern consumer culture in the West (Shapiro, 1980; Zavisca, 2005).

"Command consumption" and "the choice of the necessary" 
Although the "khrushchevki" flats were small and plain, they represented a significant improvement in the beneficiaries' living conditions. As they started to furnish and decorate their new homes, they experienced the conditions of the present in relation to their recent experience and in comparison to the lives of their parents or grandparents, as well as of relatives still living in rural conditions. Many had been rolling stones before they came to rest, at last, in their khrushchevka, their autobiographical narratives punctuated by dispossession, privation and dislocation. They personify the macrohistorical developments the Soviet Union had undergone: collectivization, and dekulakization, purges, wartime dislocation and privation, postwar reconstruction and the construction of new industrial cities, austerity and famine (1947, Filtzer, 2011), the postwar geopolitical settlement and the Cold War, with its effects on circulation of people, information and goods. Informants repeatedly emphasized that they "had nothing". For those born in the 1920s, the 1950s were a period in their own lives when they were studying or just beginning to establish themselves in jobs and careers, as well as starting families and, in many cases, setting up home on their own for the first time, a process accelerated by the move to new flats for nuclear families.

Fatyma, a Tatar' born 1930, from a rural background and with only five years of schooling, moved in the postwar period to Kazan', where she worked in a brick factory.[1] The move from the kolkhoz, where wages were paid in kind, to the city and industrial labor also marked her entry into a cash economy, being the first time in her life that she received cash wages, although her pay (27 rubles/month) was barely enough to subsist on. "The labor was heavy. But what to eat? We'd soak bread, sprinkle sugar on it and eat that for dinner. And where's the butter? Where's the margarine? There's nothing!" The consumption dispositions of poverty, thrift, recycling and using up, instilled in her while growing up in the impoverished countryside during the war, remained with Fatyma even in post-Soviet times, and she still would not throw bread away even when stale. "I've never forgotten the war," she says. Although she and her husband considered themselves very poor, their rural relatives were even worse off, so they helped them by sending money and furniture they no longer wanted. Evgeniia, a Leningrad schoolteacher born in the 1920s, also emphasized poverty as the common experience of everyone she knew in the postwar period. Like Fatyma, she characterizes their consumption in terms of subsistence on the most humble foods: potatoes, cabbage and herring. Describing a culture, in the late 1940s-1950s, of getting by, making do and mending, using up, recycling, and sharing, she illustrates this in relation to clothing and fabric, which were still rationed after the war, recalling that, as students in the postwar 
years, she and her friends shared a single best dress between them, for use, in turn, by whoever had a date.

Evgeniia, Fatyma and others presented a model of consumption as satisfaction of essential needs, defined by cutting their coat to fit their cloth and by replacement cycles based only on wearing out or using up. Dmitiri (born 1928) says, "We lived according to our means. We dressed modestly. If we got a coat then [it had to last] for ten years or more." As they describe this early period, in their acquisition of furniture or clothes no part was played by fashion or by reflexive, self-defining, cultural considerations, aside from handed down norms of propriety or decency. Many dismissed suggestions that the way they furnished and equipped their new flats might have been guided by any kind of ideal of home or image or the lifestyle to be lived there, even though the advice on how to consume for the home and make a modern and tasteful home in the "contemporary style" was so ubiquitous in the media of the 1960 s as to be unavoidable.

Interviewer: Do you remember if there was such a concept as "fashion" at that time?

Fatyma: There was nothing. What fashion!

I. Fashion for things...

F. For things? Nothing of the sort! Just as long as a thing was well made, as long as it was good. There was no fashion. So long as there weren't any holes. We didn't see fashion.

I. So how did you choose cupboards? By color? By shape? Or to be strong?

F. No. It was hard. There were queues. You'd go again and again. And then a cleaner or someone in the shop, you speak to her and she tells you that they're going to deliver something, come along. So you go and you buy.

I. You took whatever there was?

F. Of course. What kind of "by color"!

The response of Roza, another Tatar woman, who worked in the clothing industry in Kazan', is typical of many: "Whatever you saw in the shops, if you liked it you bought it-what advice?--and if money allowed." Nina I.S. a post-office employee in Kazan', born in 1939, also denied that "fashion" or advice on good taste shaped her purchase decisions or engendered desire.

Nina I.S.: Why take advice? After all, there were shops--hardware, furniture shops. If I need a saucepan I go to the hardware shop. And I choose what I like. If I need furniture I also go and start to look. I need a table. I've already bought a bed so that doesn't interest me any longer. Then when I've saved up some money I'll immediately run and buy a table [...] We didn't chase after fashion. Back then everything was made more sturdily [prochnee] and everything was better. But what they advertise now...

Despite the interviewers' care to phrase their questions appropriately, the subjects often greeted the suggestion that they might have sought to achieve some conscious 
aesthetic "look" or lifestyle in their interior, or that their homemaking and purchase decisions might be guided by principles of style and taste, as inappropriate in regard to "simple people" like themselves. Some (e.g. Vladimir and Elena, Kazan') even denied seeking cosiness (uiutnost'), conventionally the essential quality of homeyness (Reid, 2010). Dmitrii and his wife Valentina, also residents of Kazan', had changed little in their interior since they first moved in and set up home. They explain that they had no interest in home decorating or in fashioning an aesthetic style and lifestyle that would distinguish them and their apartment, because they were "simple people".

I.: And back in the sixties? How did you furnish your apartment then?[...] Did people have any desire to stand out somehow?

Dmitrii: Of course not. We're just simple people.

I.: I mean did you want to make an original apartment?

D.: No, no.

I.: Was there any kind of decoration in the apartment? Did you want to make it beautiful?

D.: No, we also don't like that. We'll change the wallpaper once more if we have the energy. It's necessary to change the wallpaper. It gets old.

They would only change the wallpaper once it was worn out, motivated by a sense of decency (not to look shabby) rather than by any desire for a change in style, to keep up with fashion or objectify their self-identity or status. Protesting their own "ordinariness," they denied any desire to exercise taste and distinguish themselves through their interior and emphasized instead, the contingency of their homemaking on the dictates of necessity.

I.: Did you consult with your friends about how to furnish your apartment interior?

D.: That didn't happen with us because we are simple [...] As far as this taste and other choices [goes]: somehow we didn't ever think about it, and didn't even consider it. What there is there is. Whatever we could get hold of, so be it.

Evgeniia accumulated her furniture serendipitously; she got a bed off a dump, while other furniture was given to her by grateful students and their parents. Other informants also spoke of the exercise of taste and aesthetic choice as a luxury that was unavailable to them. As Nina D.K. (Samara, born 1927) put it: "we did what we had to live." Zoya (Kaluga) described the nature of Soviet consumption:

I.: So how did you choose, for example, this chandelier?

Zoya: Well that was also by chance.

I.: By chance?

Z.: They provide--you run. Oh, they'd put something [on sale] and you'd get hold of [it].

These responses represent their Soviet-era consumption as if it was an unconscious, spontaneous, even Pavlovian reflex to the agency of others. Zoya's formulation "they 
provide--you run" implies that the command economy also commanded consumption, dictating it through state planning, production and distribution. Their consumption for the home appears as natural, rational, and "real," triggered by need or availability, not manipulated or "distorted" by a culture of images aimed at producing inauthentic, culturally induced desires. It also apparently lacked the reflexive, individual selfdefining choices, which for Anthony Giddens define the specifically modern relation between consumption and self-identity (Giddens, 1991). Shortage seemingly precluded making the home an aesthetic identity project. In conditions of poverty and scarcity, fashion and aesthetic discernment are, they imply, a luxury or privilege, since both presume the possibility of choice (cf. Makovicky, 2007, pp. 289-90, p. 305 n.4).

The consumption dispositions my informants present reproduce (unwittingly) a logic that Pierre Bourdieu called "the choice of the necessary" (Bourdieu, 1984, pp. 373-97). According to Bourdieu (referring to France), working-class practices are a direct response to economic conditions, aimed at saving money, time and effort: "they stem from a choice of the necessary ('That's not for us'), both in the sense of what is technically necessary, 'practical' (or, as others would say, functional), i.e., needed in order to 'get by,' to do 'the proper thing and no more,' and of what is imposed by an economic and social necessity, condemning 'simple,' 'modest' people to 'simple,' 'modest' tastes." Things are reduced to their technical function--"'a simple little dress,' 'solid' furniture" - rather than being objects of desire and cultural or symbolic capital:

Thus nothing is more alien to working-class women than the typically bourgeois idea of making each object in the home the occasion for an aesthetic choice, of extending the intention of harmony or beauty even into the bathroom or kitchen, places strictly defined by their function, or of involving specifically aesthetic criteria in the choice of a saucepan or cupboard. (Bourdieu 1984: 379-80)

As we have seen, the informants' accounts seem to confirm Bourdieu's analysis. However, a number of scholars have critiqued Bourdieu and others' assumption that lack of abundance or of wealth precludes sophisticated ideas about consumption as a fallacy based on an essentialist and ahistorical construction of authentic "real need" (Glennie, 1995, p. 177). Don Slater charged that Bourdieu's conception of the "choice of the necessary" reproduces some "now-familiar prejudices and wishful thing--that somehow the working class (or women or other others) are unclouded by ideology [...] because they are compelled by real necessity, by a functional relation to things, or because they know things through direct labour, through their hands" (Slater, 1997, p. 163; Trentmann, 2004, p. 375; Baudrillard, 1981, pp. 63-87, 2005). Anthropologist Daniel Miller has argued that abundance of things is not a necessary precondition for 
sophisticated discourse about goods; this can take place even in the absence of such abundance or of the resources to acquire them (Miller, 2010, p. 5).

Bourdieu describes the "choice of the necessary" as a specifically working class habitus. Among my informants, factors such as education, income and location (provincial/metropolitan) may have played some role in protestations that cultural considerations and reflexivity about choices (e.g. the exercise of aesthetic choice or search for individual style) were inappropriate for, or unavailable to them as "simple people" (cf. Bourdieu, 1984, pp. 379-80). However, it is not only the least advantaged among my subjects (manual workers and former kolkhoz peasants) who deny that the home was an aesthetic or identity project, presenting it as a matter of simple necessity, opportunity, and doing "as it is done". Diliara (an ethnic Tatar, also in Kazan') occupied a high position both as a leading international scientist and as a party secretary, yet she also denied that the home was either an identity project or an aesthetic one, in terms similar to Dmitrii's, Evgeniia's and Zoya's above. "What's style got to do with it? Wigwam. Wigwam style."

In the next section we will begin to trouble the apparently simple correlation between essential needs and consumption for the new home. Informants might repeat such truisms as "beggars can't be choosers" in their recollections of Soviet-era consumption and home making, but these are only part of the story. Many of the interviews are selfcontradictory, moving on swiftly from assertions of "having nothing" to inventories of all the things they did have or soon acquired. Such contradictions suggest that memories of shortage and basic satisfaction of needs are selective as well as relative and historically contingent (engendered in part by generational conflict and the present-day context of the interview). To question the deterministic causality of "they provide--we run" it is useful to consider consumption's constitutive others: ridding and abstention (Gregson, 2007). We will look first at the sorting process that was part of the move to new flats, both in media representations and in popular accounts and practice, and will also consider the implications of "shoppers strikes" and non-buying in a system of goods supposedly defined by "shortage." In the final section we will turn to the corollary of the process of purge and renewal: that people started for the first time to buy durables for their new apartments. To introduce an element of dynamism and historical specificity, we will attend to popular discourses of "fashion" and to cases where apparently "essential needs" changed in this period or were satisfied in new ways.

\section{"What shall we take forward into the communist future"?}

The new mass housing was expected by party ideologues and utopian modernist 
architects to produce modern and rational new people ready for the imminent transition to Communism. The Soviet media advised novosely to leave behind their handed-down and passively accumulated old furniture and to treat the new spaces as a tabula rasa. Sorting and discarding the material culture of the past, they would also slough off the last residues of atavistic, bourgeois values, attitudes, and practices that retarded the transition to Communism (e.g. Nikol'skii, 1959; Reid, 2006, 2009 for detail). Moreover, the architects argued, the physical and aesthetic exigencies of the small, rational and modern flats compelled novosely to rid themselves of old things when they moved in. Not only would old furniture not fit through the door, but its scale and aesthetic would look incongruous in the modernist, functionalist environment (e.g. Odintsova, 1961; Rybitskii, 1961).

The metaphor of leaving the past behind and embracing modernity was poignantly materialized in heaps of unwanted furniture dumped out on the street, an image that is one of the collective memories of the 1950s-60s. Many informants did indeed abandon old furniture. Even Fatyma, who espoused a "pre-industrial" or "working class" consumption morality based on need, function, wearing out and using up, disposed of old furniture even though it was still usable. Fatyma rejected her old things because they were handmade, in favor of shop-bought manufactured commodities. Despite the emphasis that public rhetoric placed on central planning and machine production in the formation of the modern socialist environment, Fatyma's material world, from the foundations to the furniture of her home, was still shaped to a significant extent by decentralized, manual, ad hoc practices (Reid, 2014). Although proud of her selfsufficiency, she saw DIY as a last resort. Having left the kolkhoz and belatedly entered a money economy in the 1950s, Fatyma also desired to enter the material relations of commodities. As soon as possible they got rid of their makeshift furniture, sending it down the career ladder of things by dispatching it to even poorer relatives in the village. Fatyma aspired to manufactured goods, as signs of progress and urbanity.

I.: "Did you like bought things better?"

F.: "Of course!!! Bought is better after all. Handmade is handmade...but shopmade is better. What we make is not manufactured [fabrichnoe] all the same. That's how."

Although the mass purge of old material culture accorded with the authoritative representations of total renewal--sloughing off the past to move forward unencumbered into the communist future-individuals dumped old furniture for a variety of reasons, not necessarily out of any conscious embrace of normative models, nor as passive response to physical exigency. Nevertheless, to cast out the old did represent an 
embrace of the modernized material environment and an expression of faith in and commitment to a better future.

At the same time, the mass ridding and renewal also posed problems for homemakerconsumers. At a specialist discussion of design for the new flats, held in 1957, one architect expressed concern at the problems facing the millions of novosely. If they dumped their old furniture they had to set about replacing it as soon as possible. But the second-hand market was so swamped with discarded furniture that people moving to new flats could make very little by selling their cast-offs, whereby their means to buy new furniture were reduced.

It is necessary to take account of the fact that new residents will have to get new furniture. But since construction is on a mass scale there will be many of them, so it will be hard to sell old furniture. It is necessary to consider that people will have to throw away practically everything they already have and buy furniture from scratch. Therefore it has to be cheap and lots of it. (TsGALI SpB 341/1/526, pp. 37-38)

This architect, along with many others, called for small-scale furniture to be massproduced and affordable, "so that it is not necessary to stand all night in queues at furniture shops and to pay for furniture with one's own blood." For, it is "our workers [who] move here, and they are hardly likely to be able to find all at once 10,000 rubles to pay for furniture and kitchen equipment" (TsGALI SpB 341/1/526, p. 38).

Furniture required a considerable cash outlay, but few of those who moved during the first wave (c. 1959-64) had any savings or disposable income, or had relatives who could help them out, and some, like Fatyma, had only recently entered a cash economy. The mass production of furniture, for which the architect called, was only just beginning in this period, and these efforts were outstripped by the rapidity with which people moved into new housing. Although the media focussed on these lucky novosely, the desire to buy new furniture was not limited to them; some who remained in old apartments wished nevertheless a share in the modern lifestyle promised, as comments in visitors' books for Art into Life indicated (TsAGM21/1/125-130; RGALI 2329/4/139). In these circumstances, to purchase items of furniture that were in high demand often required not only cash but connections and pull (blat).

Moreover, experts on the interior strongly advised homemakers to eschew eclecticism and furnish their interiors in a unified "contemporary" style, prioritizing the ensemble. To buy a matching suite of furniture was a quite different undertaking from the serendipitous, piecemeal accumulation of furniture, as and when the opportunity arose, as implied by the equation "they gave--we ran." It involved planning, saving up, deferral of gratification, finding something to fit an ideal of home imagined in advance. 
To enable the population to purchase more expensive consumer durables, in late 1959 the Soviet regime introduced a state scheme of payment on credit, financed by the state bank (USSR Council of Ministers, 1959; Boiter, 1960). Thereby the regime facilitated and sanctioned a shift away from the consumption morality that a number of my informants articulated above: that one should cut one's coat to fit one's cloth and consume within one's means. Payment on credit or hire purchase was, of course, an important factor in the developing consumer culture in the postwar West. Although the system was less developed, informants speak of getting "everything on credit."

Lack of purchasing power and problems of supply and distribution have received wide attention as part of the shortage model, adduced as evidence of the unviability of a planned economy. I want to draw attention, however, to a different lesson that can be drawn from this story of mass housewarming. My informants' tales of sorting, ridding and redistribution make clear that an essentialist and static conception of needs is not adequate to comprehend the nature of Soviet consumption in the long 1960s. As the architect indicated--and the dumps of discarded furniture substantiated--the problem of furnishing was not simply a shortage of furniture in general. It was a shortage of particular types and styles of furniture, with their accompanying values and meanings. There was furniture and plenty of it, but it was sitting rejected on rubbish heaps, without economic, emotional or aesthetic value. This suggests that even where shortage of goods and of resources to acquire them played a significant role in people's material circumstances, the experience of consumption and the choices made at the "consumption junction" (Cowan, 1989) are not adequately explained by the essentialist conception of the "choice of the necessary." Questions of culture and meaning must also be taken into account: the role of desire, image, ideals, taste, affect, self-identity, semiotics, meaning and the dynamic, diachronic element of "fashion," all of which have been identified as defining characteristics of "modern consumer culture" in the West (Campbell, 1987; Baudrillard, 2005).

Furthermore, the rejection of handed-down or homespun things combined with a selective rejection of manufactured goods. Evidence that Soviet consumers were exercising choice, if only through non-consumption or anti-consumption, began to attract the attention of Soviet economic specialists in the late 1950s. They debated and sought solutions for a problem that may seem counterintuitive: the paradox of "shoppers' strikes" and gluts in what has been assumed to be a "shortage economy" and sellers' market. Consumers were choosing not to buy, as a result of which certain items piled up unsold on warehouse shelves. Soviet economic reformers recognized that the 
issue of non-buying made it necessary to take account of the decentralized and spontaneous agency of the consumer, and they called for the study of demand to enable forecasting (Skovoroda, 1960; Moiseev et al., 1961; Goldman, 1968, p. 35 n.12). In accordance with a 1965 decree, an All-Union Scientific Research Institute for the Study of the Population's Demand for Consumer Goods and Market Prices for Trade (VNIIKS) was set up in 1966 to develop methods for study of the population's demands for consumer goods (RGAE/RGANTD 375/1/6; 375/1/13, p. 14; Struev, 1964; Shapiro, 1980; Katz, 1974, p. 71; Reid, 2006, 2013b). Some reformist economists came close to a heretical acknowledgment of the role of market forces even in the socialist planned economy, challenging the Cold War binary organization of the world into two antithetical systems. Such proposals were short-lived; VNIIKS fell from favor after 1968 and was closed in 1972. However, they left a legacy: a significant by-product of these debates, and of the development of institutes and methodologies for market research, was the discursive production of the "Soviet consumer."

\section{"And then we started to buy": becoming demanding and discerning consumers}

The media established a direct link between new flats and new needs for furniture, presenting ridding and buying in a symbiotic, causal and sequential relationship. As we saw, ideologues and planners acknowledged that mass provision of housing engendered a legitimate need for more consumer goods, of new types and in new styles (e.g. Khrushchev, 1959b; Ogonek, 1959; Blashkevich, 1957). Thus the rebirth of the "new Soviet person" as homemaker and consumer was presented in Khrushchev-era discourse as if it was a natural, inevitable effect of the move to new flats, dictated by the new environment that materialized the architects' and planners' utopian, rationalist vision of modernity.

The move to new flats, in many of my subjects' narratives, marks the beginning of a process of settling, accumulating and becoming consumers in a new, qualitatively different sense over the course of the next two decades. Remembering back to the late 1950s or early 1960s when they first moved in, many informants begin by talking about the emptiness of the new apartment, though they often present this not simply as a negative, "lack," but as possibility and freedom from clutter and convention. From this nil-point of commodity-lessness and reliance on handed-down or handmade material culture, and assertions of the choice of the necessary, they go on to express variously the idea: "then we started to buy." Within a few years of relocating they began to accumulate consumer goods for the new apartment. "And bit by bit we bought all this," said Galina D.S. (Kaluga, born c. 1945) who moved to a khrushchevka in 1964. For Nina S. 
(Leningrad, higher education), coming to rest in a modern separate apartment was also the beginning of homemaking and accumulating. Around 1960 she moved by car to a two-room apartment in Lomonosov. By the time they came to pack up and move house again in 1966 (to Murmansk, following her army officer husband's military posting) she no longer had a car-full of possessions but a whole container, packed for her by the soldiers from her husband's regiment.

Mariia (born 1928, a worker in the low-paid sewing industry, with secondary education) moved from a privately rented room to a separate apartment in a brick khrushchevka in Kaluga in 1960. Mariia's move was part of process of going up in the world as it followed her promotion to shopfloor manager. The furniture in the private room was old, reflecting tastes and practices rooted in the pre-revolutionary past. She recalls an old bed and an etazherka ("whatnot"), a small display stand of shelves that had been mandatory in "proper" interiors until the late 1950s-60s at which time, according to many, it "went out of fashion." When she first saw the new apartment it seemed a vast empty space, but Mariia remembers the passage from emptiness and poverty to accumulating possessions: "And then bit by bit we began to set up home [...] I was contented, and so life changed somehow and got happier."

Above, Fatyma and Evgeniia described an economic level at which most of their income went on consumables. While individual cases varied in degree and timing, the composite biography of my informants traces a common trajectory from a time when their household budget was spent entirely on consumables, to accumulating durables, and then replacing and upgrading them. A shift in the balance of household budgets from the subsistence described by Fatyma and Evgeniia ("potatoes, cabbage and herring") indicated their increased purchasing power, as well as significant improvements in the supply of goods. Other foreign observers remarked on the signs of growing prosperity and consumption levels in the mid-sixties, as consumer durables were acquired by most Soviet families (Goldman, 1968; Skurski, 1983, pp. 5-6). Per capita consumption grew quite rapidly under Khrushchev, although it slowed down in the early 1960s (Hanson, 1968, 2003; Nove, 1970).

Importantly for our consideration of modern consumer culture, the shift was not only a quantitative matter of accumulating things; it was also qualitative. If, as they often assert, furnishing the apartment was at first a matter of getting whatever they could get hold of or afford, over the next decade some replaced their first stop-gaps and began to make choices in regard to aesthetic factors such as style, finish, quality, and to considerations of social meaning and identity. The process of homemaking included the 
accumulation of items that would, not long before, have been considered luxuries, such as a sideboard or display cabinet, in which they could construct a material narrative of identity (Reid, 2013a). Mariia moved from subsistence and homespun to saving up to buy an oak wardrobe. This was not a matter of "simple need"--they already had a cupboard to keep their clothes in--but of preference and style or "fashion" (moda). Once they were able to afford a new wardrobe they threw out the old one because, she says, it was not "fashionable."

Mariia: We saved up for a wardrobe and threw out the old one.

I.: Why, was it very old or something? [... ]

M.: Well yes, it wasn't fashionable.

They also began to acquire entirely new types of commodities: electrical appliances. And not only "labor saving" machines, such as a vacuum cleaner or refrigerator, but also "time-using" ones. Benefiting from the increased free time provided by Khrushchev's reduction of the working week, along with the shift toward home-based leisure, which the provision of separate apartments enabled, people listened to music of all sorts on new record players, radiolas and tape recorders. Mariia had a fashionable, "contemporary style" radio set on splayed, tapering legs, a record player and records to play on it, which they collected whenever they travelled anywhere. Tourism, leisure and technology all became part of a modern Soviet lifestyle.

Mariia's "rags to riches" story--accumulating, replacing, upgrading--is repeated many times over in the narratives. At some time in the long 1960s, informants made a transition from "having nothing" to gradually accumulating furniture, appliances, and luxury goods such as decorative arts. While electrical appliances are not the focus of the present paper (see Reid, 2013b), the acquisition and replacement or upgrading of such goods marked a significant qualitative shift in consumption (Goldman, 1968, p. 55). The initial outlay for the purchase also tied people into other regular outlays including consumption of electricity. Many also speak of a sequence of upgrades, graduating quickly from black and white televisions to color sets and more prestigious models, or replacing their first washing machines and refrigerators by fully automatic and selfdefrosting ones. Even Galina, an impoverished construction worker in Apatity, who, for want of other accommodation, had lived in barn when she first moved there from Belorussia, got a refrigerator and a television. People purchased televisions at a remarkably rapid pace even in the 1950s when they insist on their deep poverty and when they were still living in cramped rooms (cf. Roth-Ey, 2007).

Soviet consumers' behavior began to change in other ways too, which some western 
observers tried to define at the time. Donald Schwartz sketches a narrative of progress that is confirmed by my interviews, from satisfaction of basic needs to accumulation, refinement, discerning consumption, and the exercise of choice (Schwartz, 1982, p. 109, cf. Millar, 1985). We will explore this process in more detail in relation to three categories, all of which demonstrate that the meaning of purchases was not limited to satisfaction of "natural" needs or a Pavlovian reflex to central provision. They were made in accordance with aspirations, desire, ideals, meanings, and changing "fashion": beds and the culture of sleep; color and finish; and buying furniture in suites and matching sets rather than accumulating eclectic items piecemeal.

\section{Beds and the modernization of the culture of sleep}

We saw that informants commonly espoused the "choice-of-the-necessary" model in their own narratives and denied pursuing any kind of conscious program in furnishing their apartments. However, we also found that the situation was sometimes more complex and contradictory. Attitudes and practices were in the process of transformation in the course of the 1960s-70s; new moralities of consumption began to contend with established dispositions. The shift from "filling essential needs" to a form of "modern consumption" can be examined in regard to one of the "essential" items of the home, as a place of rest: beds.

Beds, in the 1950s and early 1960s, were an item of furniture that one would expect to have for life, only replacing the mattress periodically. Even when informants say they brought "nothing" to the new apartment, they often make an exception for the bed. They represent beds as a matter of primary necessity when they first moved in. Asked, "what did you buy first?" Nina in Kazan' replied: "a bed of course." A metal bedstead was also the first thing Fatyma purchased. Roza, the Tatar sewing industry worker in Kazan', had to sleep on the floor when she and her husband first moved in because their bed had broken. When she could no longer tolerate this, she resorted to bribing a shop deliveryman in order to bypass the queue and get a new divan. Evgeniia also acquired a metal bedstead as a priority, although she did not buy hers from a shop, either over or under the counter, but found it on a dump where someone had thrown it out.

The need for sleep seems so natural and essential that the equipment for it may also be taken for granted. Yet even regarding sleep, needs are culturally constructed, as comparison with other cultures shows (Cieraad, 2007, pp. 177-78). Sleep and its associated material culture are historically contingent, subject to change with time. Beds are not simply physical supports for sleeping but are imbricated in cultural practices, 
social relations and systems of meaning. Thus the bed and associated practices serve as a useful case study to track changing consumption behavior.

The bed was identified as a prime target for modernization and rationalization in the Khrushchev era, resuming the efforts of the campaign for the "new way of life" and "new person" in the 1920s. Design and taste reformers were especially concerned to root out domestic practices of displaying wealth and status, and these included the treatment of the bed. In the traditional Russian and Tatar home, the bed--an iron frame with a mattress--would be set aside during the day as a permanent fixture in the room, the support for a display of wealth and good housekeeping materialized in puffed-up feather pillows and fine white lace, known as shishki (cones) (Buchli, 1999, pp. 88-9; Chizhikova, 1979). A number of my informants recall this practice of creating "show beds," and some from rural backgrounds, such as the Russian Nina I.S. and the Tatar Fatyma in Kazan', still continued to make shishki in the mid 2000s, although Nina had modernized hers with a Chinese satin bedspread in strong aniline dyes (Reid, 2010). The treatment of the bed as a site for display of family wealth and the housewife's prowess was condemned in the late 1950s for its irrational waste of space and elevation of display over function, its un-socialist claims to status through material wealth, and its unreconstructed identification of women with bourgeois property relations and unproductive labor for the private home (Sharov and Poliachek, 1960; Harris, 2003, p. 529). The show bed became associated with the past, with petit-bourgeois values (meshchanstvo), philistine bad taste, and with everything backward and rural; it was the antithesis of the modern urban socialist civilization, which the new flats and "contemporary style" were supposed to represent.

In the modern furniture sets produced under the auspices of the "contemporary style", the traditional iron bedstead, associated with these "atavistic," "petit-bourgeois" customs passed down from the preindustrial past, was replaced by a low wooden divan which served as a seat during the day. This displacement was rationalized as a response to the need to make efficient use of space, for all rooms in the flats were used for both night and daytime uses. However, the purge of the bed as a permanent fixture in the room was also ideological, reflecting two principles which the Bolsheviks had shared with broader modernist tendencies: the rejection of non-functional, conventionalized display of prosperity; and the suppression of rest in favor of constant activity, wakefulness and mobility, as symbolized by Rakhmetov's bed of nails. In the 1920s, Constructivist artists had designed transformable furniture for the new active person; the suppression of sleep was marked by the fact that its equipment was hidden away 
during the day or converted into furniture for daytime, waking use (Matich, 1996; Cieraad, 2005; Reid, 2010). Resuming aspects of the earlier utopian campaign for physical as well as political mobilization, the modernizing specialists of the Khrushchev era set out to replace traditional styles of furniture by light, low and often multipurpose ones that made efficient "rational" use of space and of materials.

<INSERT FIGURE 3 HERE >

If my subjects had brought an old metal bedstead to the new apartment, many soon replaced it by the new furniture type, the divan or bed-settee. Their narratives indicate that, by the late 1950s, they had begun to discard metal bedsteads by choice in exchange for the modern furniture type serving the same function, the low-wooden divan that could be converted into a settee during the day. Metal bedsteads were one of the items the architect above singled out among the things accumulating on dumps. While the old beds continued to serve the physiological need of accommodating sleep just as they always had, they no longer fulfilled cultural needs associated with "fashion" and with achieving a "contemporary" interior and modern lifestyle. Even Dmitrii, when pressed on questions of taste, mentioned that they had bought a bed-settee, manufactured in Riga. Nina I.S., like Dmitrii and Fatyma, dismissed the notion of "fashion" in regard to homemaking. With time, however, Nina's spending power also increased. "Somehow we got by. And we even managed to put away money in the [savings] book." And within a few years of her moving in in 1965, she also replaced the iron bed. The descent of her once-valued metal bed down the career ladder of things was marked by its relegation from the urban apartment to the dacha (or in other cases to relatives in the countryside) and then being stolen for scrap metal.

I.: "Why did you throw out the iron beds? Were they uncomfortable?"

Nina I.S.: "No not because of that. Yes, of course, people already started to buy wooden ones. It [the bed] was already old. Then we took it to the [dacha] garden. And there it was stolen for the metal... [...] We moved in with a metal one. So it was metal. Some had [wooden divans] earlier. Those who were able to. Those who had money bought furniture. It was always in the shops.

Mariia who (above) bought a new wardrobe because the old one was outmoded, also specifically cited changing fashion as a reason for replacing her old bedstead by the new type of divan. "We decided that beds were not fashionable."

Being discerning: color schemes

As the modernization of the bed exemplifies, nonessential considerations of aesthetics status and meaning also began to engage even my self-styled "simple folk", alongside matters of function and sheer physical fit. These included also the search for specific 
styles or quality of finish and surface, the aim for color coordination or stylistic unity, and matters of self-fashioning and social distinctions.

\section{$<$ INSERT FIGURE 4 HERE $>$}

Earlier I cited Fatyma's denial that color was a consideration in acquiring things for her flat and her implication that it was a "luxury." However, color and other surface qualities mattered enough to other informants for them to invest significant effort and resources in producing their desired look. With time, Nina S. started collecting furniture not only to fill a specific function but to match her color scheme. A number of informants attached particular value to dark, polished wood. There is some correlation between such "aesthetic" consumption and possession of the cultural capital associated with metropolitan and intelligentsia status. Inna, for example, a Leningrad librarian (a lowpaid but respected, intelligentsia occupation) describes the huge efforts she put in to finding curtain fabric in the right shade of "Bordeaux". However, consumption in accordance with an ideal of home, or of a self they aspired to be, was not limited to the wealthiest and most privileged intelligentsia and metropolitan informants. Diana, a retired factory worker in Kaluga, had suffered repeated dislocation during the war. Separated from her family, she had also missed out on school education, and her health was permanently damaged by wartime malnutrition. In 1948, she arrived in Kaluga, a city that had been in the frontline and was still devastated. Although located in a traditional woodworking area, Kaluga's furniture factory had closed during the war. As part of the postwar reconstruction, the factory reopened and resumed production (c. 1950s). However, only products of the local factory were available. She describes it as "all one color, all yellow". For Diana it wasn't enough to have furniture that was all the same and identical to everyone else's, even if it fulfilled its function adequately. She wanted not only to be able to equip her flat but to be able to make choices in accordance with her own taste and idea of how she wanted her interior to look. By the 1970s "there was already plenty of furniture. This polished furniture I bought in 1975 and I threw out [the old]... I was tired of that yellow furniture." She began to buy furniture from Moscow, because the capital was not only better supplied but offered more choice, since there were numerous furniture workshops there. Diana replaced her furniture not because it was worn out but because she was "tired of it". She wanted a change and to exercise choice to fit her sense of self and aspirations for her home and to make it different from others'.

Suites and matching sets 
To be different, to stand out through their style of interior decorating, was essential for Marina's parents in Samara. Marina, a theatre designer, the youngest of my informants (forty-five years old) and probably the most style conscious, describes her parents' taste as "avant-garde" or hipster. Her fashion-conscious parents were prepared to go to some lengths to achieve the visual appearance they sought, including traveling to Moscow to get furniture and then having to camp out at the railway station overnight with their purchases. Asked about what counted as luxury or prestigious in the 1960s, Marina speaks of ensembles and the prestige of having matching china services:

Luxury? Well, probably furnishing each of the rooms so that there was a bedroom, a children's room, and a living room. That was luxury. [...] In the sixties it was probably more modest. But they had [dinner or tea] services. To have a service at home--that was good. Well, for example, to have kitchen dishes all one color, that's also good.

A number of the interviewees began to acquire not only individual items of furniture but complete suites. Nina S.'s (Leningrad) process of making the standard flat into home was marked by the purchase of a suite. Others, too, recall the purchase of a whole matching "living room" or "bedroom" as a significant moment. As the architect cited above indicated, to furnish an apartment all at once required a very significant outlay that lay beyond many people's means at least until the 1970s. It implied long-term planning, saving, and deferral of gratification in order to achieve a particular ideal interior.

For Roza, the purchase of a matching suite marked her attainment of a comfortable, stable, even "middle class" respectability. Roza had also suffered dislocation and poverty in her wartime childhood. Her Tatar family had owned a village shop, but their property was confiscated on the eve of the war, leaving them homeless and destitute. When Roza started to set up home in the city as a young adult, her pay, in the sewing industry, was low and her mother was unable to help her financially. However, her older sister was very resourceful and went to work in the Far North, where pay was higher, and she had helped Roza and her husband with the down payment on an apartment in a cooperative khrushchevka, to which they moved in 1965. In 1978 they paid a supplement to move to a two-room flat in the same block. Although they might have found a better flat elsewhere, they chose to stay because it was in a prestigious area in the centre of the city and this mattered to them. By the mid-sixties, when they moved into and furnished the first apartment, Roza says, furniture was freely available to buy, but the furniture was also pale. As soon as they could do so, in the early 1970s, they got rid of the first set of furniture and bought a new, dark living room suite consisting of a table, two sideboards, a bedside cabinet, six chairs and two armchairs. "I liked everything about it. 
A living room suite: sideboard, bookshelves, all together. [...] Until then there was pale furniture. But fashion changes after all. I wanted dark furniture. We had a combination, all the furniture together--it was called a 'living room'." Roza's new furniture was triply prestigious, marking their social ascent: it was a suite; and it was dark, stained wood, and furthermore, it came from the Soviet "near West", from Riga, an origin that operated as a mark of quality and style. By the 1970s Roza not only made choices based on taste and aspirations. She had more than enough. She describes how she had stores of unused rugs and wallpaper well beyond her needs. What is more, the paper she had on her walls had the elevated status of being "As seen on TV": "On television, I remember, we saw it in several films and I say: 'There's our wallpaper!'”

\section{Conclusion}

My informants began by presenting themselves as lacking agency, desires and ideas about consumer goods, as if they were driven simply by (non-)availability, unchanging essential needs, and "the choice of the necessary." If this were the whole story it might reconfirm the Cold War construction of Soviet relations with goods as the pre-modern "other" of the West's dynamic consumer society, contrasting the former's natural needs with the latter's constructed desires. However, the subjects' discussions of fashion, prestige, color and other preferences--including many more we have not had space to discuss here, such as choices between imported and domestic furniture-make clear that an essentialist and static conception of satisfaction of needs is not adequate to understand the changing nature and meanings of Soviet consumption in the long 1960s.

The interviews suggest that a qualitative shift in the culture of consumption was experienced in the course of the 1960s-70s. By the 1970s, and in some cases sooner, homemakers were not only making the "choice of the necessary," dictated by problems of sourcing, financing and securing furniture. Nor were they simply consuming and accumulating more commodities. In circumstances where influential images of a desirable modern lifestyle circulated widely, albeit under the guise of "advice" rather than commercial advertising, they were making aesthetic or semiotic distinctions between functionally identical goods, concerned to find the right furniture to fit an ensemble, lifestyle and sense of self.

\section{References}

Baiar, O. and Blashekevich, R. (1962), Kvartira i ee ubranstvo, Stroiizdat, Moscow.

Barker, A.M. (Ed.) (1999), Consuming Russia: Popular Culture, Sex, and Society since Gorbachev, Duke University Press, Durham NC.

Baudrillard, J. (1981), For a Critique of the Political Economy of the Sign, Telos, St Louis, MO. 
Baudrillard, J. (2005), The System of Objects, Verso, London.

Blashkevich, R. (1957), “Kakoi dolzhna byt' massovaia odnosemeinaia kvartira? Arkhitektura SSSR, No. 5, pp. 5-9.

Bourdieu, P. (1984), Distinction: A Social Critique of the Judgment of Taste, trans. R. Nice, Cambridge University Press, Cambridge, Eng.

Bren, P. and Neuburger, M. (Eds) (2012), Communism Unwrapped: Consumption in Cold War Eastern Europe, Oxford University Press, Oxford.

Brown, K. (2013), Plutopia: Nuclear Families, Atomic Cities, and the Great Soviet and American Plutonium Disasters, Oxford University Press, Oxford.

Buchli, V. (1999), An Archaeology of Socialism, Berg, Oxford.

Bushnell, J. (1980), "The 'New Soviet Man' turns Pessimist," in Cohen, S.F., Rabinowitch, A., Sharlet, R. and Macmillan, R. (Eds), The Soviet Union since Stalin London, pp. 179-99.

Campbell, C. (1987), The Romantic Ethic and the Spirit of Modern Consumerism, Blackwell, Oxford.

Campbell, C. (1995), "The Sociology of Consumption," in Acknowledging Consumption, in Miller, D. (Ed.), Acknowledging Consumption, Routledge, London, pp. 103-4.

Castillo, Greg (2010), Cold War on the Home Front: the Soft Power of Midcentury Design University of Minnesota Press, Minneapolis, Minn.

Chizhikova, L. (1979), "Zhilishche russkikh," in Rabinovich, M. (Ed.), Material'naia kul'tura kompaktnykh etnicheskikh grupp na Ukraine, Nauka, Moscow.

Cieraad, I. (2007), "Sleeping Around: The Bed from Antiquity to Now," Journal of Design History, Vol. 20 No. 2, pp. 177-178.

Cieraad, I. (2005), "A Nation Under Reconstruction Never Sleeps: the Rise and fall of the Dutch Wall Bed," Journal of Design History, Vol. 18 No. 2, pp. 167-177.

Cohen, L. (2003), A Consumers' Republic: The Politics of Mass Consumption in Postwar America, Vintage Books, New York, NY.

Cowan, R.S. (1989), "The Consumption Junction: A Proposal for Research Strategies in the Sociology of Technology," in Bijker, W., Hughes, T., Pinch, T., The Social Construction of Technological Systems, MIT Press, Cambridge, MA, pp. 261-80.

Cox, R. (2003), "All This Can Be Yours!: Soviet Commercial Advertising and the Social Construction of Space, 1928-1956," in Dobrenko, E. and Naiman, E. (Eds), The Landscape of Stalinism: The Art and Ideology of Soviet Space, University of Washington Press, Seattle, WA.

DiMaio, A. (1974), Soviet Urban Housing: Problems and Policies, Praeger, New York, NY.

Dobson, R. (1994), "Communism's Legacy and Russian Youth," in Millar, J.R. and Wolchik, S.L. (Eds), The Social Legacy of Communism, Cambridge University Press, Cambridge, pp. 229-51.

Fehér, F., Heller, Á., Márkus, G. (1984), Dictatorship Over Needs: An Analysis of Soviet Societies, Basil Blackwell, Oxford.

Field, D. (2007), Private Life and Communist Morality in Khrushchev's Russia, Peter Lang, New York, NY.

Filonovich, Iu. (1959), “Veshchi - ne khoziaeva, a slugi!” Izvestiia, No. 163, 11 July, p. 4.

Filtzer, D. (2011), The Hazards of Urban Life in Late Stalinist Russia: Health, Hygiene, and 
Living Standards, 1943-1953, Cambridge University Press, Cambridge, Eng.

Fitzpatrick, S. (1992), "Becoming Cultured. Socialist Realism and the Representation of Taste and Privilege," in Fitzpatrick, S. (Ed.), The Cultural Front: Power and Culture in Revolutionary Russia, Cornell University Press, Ithaca, NY, pp. 216-37.

Giddens, A. (1991), Modernity and Self-Identity: Self and Society in the Late Modern Age, Polity, Cambridge, Eng.

Gilison, J.M. (1975), The Soviet Image of Utopia, Johns Hopkins University Press, Baltimore, MD.

Glennie, P. (1995), "Consumption within Historical Studies," in Miller, D. (Ed.), Acknowledging Consumption, Routledge, London, pp. 164-203.

Goldman, M. (1963), Soviet Marketing: Distribution in a Controlled Economy, Free Press of Glencoe, New York, NY.

Goldman, M. (1968), The Soviet Economy: Myth and Reality, Prentice-Hall, Englewood Cliffs, NJ.

Gregson, N. (2007), Living with Things: Ridding, Accommodation, Dwelling, Sean Kingston Publishing, Wantage.

Hanson, P. (1968), The Consumer in the Soviet Economy, Macmillan, London.

Hanson, P. (1974), Advertising and Socialism: The Nature and Extent of Consumer Advertising in the Soviet Union, Poland, Hungary and Yugoslavia, Macmillan, London.

Hanson, P. (2003), The Rise and Fall of the Soviet Economy: An Economic History of the USSR from 1945, Longman, London.

Harris, S. (2003), “Moving to the Separate Apartment: Building, Distributing, Furnishing, and Living in Urban Housing in Soviet Russia, 1950s-1960s," Ph.D. diss., University of Chicago.

Harris, S. (2012), Communism on Tomorrow Street: Mass Housing and Everyday Life after Stalin, Woodrow Wilson Center Press, Washington, DC.

Harrison, M. (2002), "Coercion, Compliance, and the Collapse of the Soviet Command Economy," Economic History Review, Vol. 55 No. 3, pp. 397-433.

Hessler, J. (1996), “Culture of Shortages: A Social History of Soviet Trade, 1917-1953,” PhD diss., University of Chicago.

Hessler, J. (2000), "Cultured Trade: The Stalinist Turn towards Consumerism," in Fitzpatrick, S. (Ed.), Stalinism: New Directions, Routledge, London, pp. 182-209.

Hodnett, G. (Ed.) (1974), Resolutions and Decisions of the Communist Party of the Soviet Union CPSU, Vol. 4: The Khrushchev Years, 1953-1964, University of Toronto Press, Toronto.

Izvestiia (1959), “Bol'she, dobrotnee, krasivee!” Izvestiia, 23 October.

Katz, A. (1973), The Politics of Economic Reform in the Soviet Union, Praeger, New York, NY.

Kelly, C. and Volkov, V. (1998), "Directed Desires: Kul'turnost' and Consumption." In Kelly, C. and Shepherd, D. (Eds), Constructing Russian Culture in the Age of Revolution, 1881-1940, Oxford University Press, Oxford, pp. 291-313.

Kerblay, B. (1983), Modern Soviet Society, translated by Rupert Swyer, Methuen, London.

Kiaer, C. (2005), Imagine No Possessions: The Socialist Objects of Russian Constructivism, 
MIT, Cambridge, MA.

Khrushchev, N.S. (1959a), Za dal'neishii pod"em proizvoditel'nykh sil strany. Rech' na Plenume TsK KPSS 26.VI.1959, Politizdat, Moscow.

Khrushchev, N.S. (1959b), O kontrol'nykh tsifrakh razvitiia narodnogo khoziaistva SSSR na 1959-1965 gody, Politizdat, Moscow.

Kornai, J. (1980), Economics of Shortage, 2 vols, North-Holland, Amsterdam.

Landsman, M. (2005), Dictatorship and Demand: The Politics of Consumerism in East Germany, Harvard University Press, Cambridge, Mass.

Makovicky, N. (2007), "Closet and Cabinet: Clutter as Cosmology," Home Cultures Vol. 4 No. 3, pp. 287-310.

Matich, O. (1996), "Remaking the Bed: Utopia in Daily Life," in Bowlt, J. and Matich, 0. (Eds), Laboratory of Dreams, Stanford University Press, Stanford, CA, pp. 59-78.

Merkel, I. (1998), "Consumer Culture in the GDR," in Strasser, S., McGovern, C. and Judt M. (Eds), Getting and Spending: European and American Consumer Societies in the Twentieth Century, Cambridge University Press, Cambridge, Eng., pp. 281-99.

Merkel, I. (1999), Utopie und Bedürfnis: Die Geschichte der Konsumkultur in der DDR Böhlau, Cologne.

Merkel, I. (2008), "Alternative Rationalities, Strange Dreams, Absurd Utopias: On Socialist Advertising and Market Research," in Pence, K. and Betts, P. (Eds), Socialist Modern: East German Everyday Culture and Politics, University of Michigan Press, Ann Arbor, MI, pp. 323-44.

Merl, S. (1997), "Sowjetisierung in der Welt des Konsums," in Jarausch, K. and Siegrist, H. (Eds), Amerikanisierung und Sowjetisierung in Deutschland 1945-1970, Campus, Frankfurt am Main, pp. 167-94.

Millar, J.R. (1985), “The Little Deal: Brezhnev's Contribution to Acquisitive Socialism," Slavic Review, Vol. 44 No. 4, pp. 694-706.

Millar, J.R. and Wolchik, S.L. (1994b), "Introduction: The Social Legacies and the Aftermath of Communism" in Millar, J.R. and Wolchik, S.L. (Eds), The Social Legacy of Communism, Cambridge University Press: Cambridge, Eng., pp. 1-28.

Millar, J.R. and Clayton, E. (1987), "Quality of Life: Subjective Measures of Relative Satisfaction," in Millar, J.R. (Ed.), Politics, Work, and Daily Life in the USSR: A Survey of Former Soviet Citizens (Cambridge University Press, Cambridge, Eng. pp. 31-57.

Miller, D. (Ed.) (1995), Acknowledging Consumption, Routledge, London.

Miller, D. (2010), Stuff, Polity Press, Cambridge, Eng.

Moiseev, V., Guz, R. and Khochinskii, M. (1961), "Nekhodovye tovary i ikh utsenka," Sovetskaia torgovlia, No. 2, pp. 41-42.

Nikol'skaia, E., Nikol'skii, M. (1963), Kniga o kul'ture byta, Profizdat, Moscow.

Nikol'skii, M. (1959), “Novyi dom - novyi byt,” Izvestiia, 19 December.

Nove, A. (1970), An Economic History of the U.S.S.R., Allen Lane, London.

Odintsova, I. (1961), "Veshchi v nashem bytu," Sovetskaia torgovlia, No. 7, pp. 51-53.

Ogonek (1959), “V novuiu kvartiru - novaia mebel'!” No. 11, 8 March. 
Pence, K. and Betts, P. (Eds) (2008), Socialist Modern: East German Everyday Culture and Politics, University of Michigan Press, Ann Arbor, MI.

Pence, K. and Betts, P. (2008), "Introduction," in Pence, K. and Betts, P. (Eds), Socialist Modern: East German Everyday Culture and Politics, University of Michigan Press, Ann Arbor, MI, pp. 1-36.

Peremyslov, A.S. (1962), Dom budushchego. (Zametki arkhitektora), Politizdat, Moscow.

Randall, A.E. (2008), The Soviet Dream World of Retail Trade and Consumption in the 1930s, Palgrave Macmillan, Basingstoke.

Reid, S.E. and Crowley, D. (Eds) (2000), Style and Socialism: Modernity and Material Culture in Post-War Eastern Europe, Berg, Oxford.

Reid, S.E. (2002), "Cold War in the Kitchen: Gender and the De-Stalinization of Consumer Taste in the Soviet Union under Khrushchev," Slavic Review, Vol. 61 No. 2, pp. 211-52.

Reid, S.E. (2006), "Khrushchev Modern: Agency and Modernization in the Soviet Home," Cahiers du Monde russe, Vol. 47 Nos. 1-2, pp. 227-68.

Reid, S.E. (2008), “'Who Will Beat Whom?' Soviet Popular Reception of the American National Exhibition in Moscow, 1959," Kritika: Explorations in Russian and Eurasian History, Vol. 9 No. 4, pp. 855-905.

Reid, S.E. (2009), "Happy Housewarming! Moving into Khrushchev-Rea Apartments," in Balina, M. and Dobrenko, E. (Eds), Petrified Utopia: Happiness, Soviet Style, Anthem Press, London, pp. 133-60.

Reid, S.E. (2010), "Communist Comfort: Socialist Modernism and the Making of Cosy Homes in the Khrushchev Era," in Adler, K.H. and Hamilton, C. (Eds), Homes and Homecomings: Gendered Histories of Domesticity and Return, Wiley-Blackwell, Oxford, pp. 11-44.

Reid, S.E. (2013a), "Everyday Aesthetics in the Khrushchev-Era Standard Apartment," Etnofoor, Vol. 24 No. 2, pp. 79-106.

Reid, S.E. (2013b), "This is Tomorrow: Becoming a Consumer in the Soviet Sixties," in Gorsuch, A. and Koenker, D. (Eds), The Socialist Sixties: Crossing Borders in the Second World, Indiana University Press, Bloomington, IN, pp. 25-65.

Reid, S.E. (2014), "Makeshift Modernity: DIY, Craft and the Virtuous Homemaker in New Soviet Housing of the 1960s," History, Culture and Modernity, Vol. 2 No. 2, pp. 87124.

Riesman, D. (1964), Abundance for What, Doubleday, New York, NY.

Roth-Ey, K. (2007), "Finding a Home for Television in the USSR, 1950-1970," Slavic Review, Vol. 66 No. 2, pp. 278-306.

Roth-Ey, K. (2011), Moscow Prime Time: How the Soviet Union Built the Media Empire that Lost the Cultural Cold War, Cornell University Press, Ithaca, NY.

Ruban, M.-E. (1962), "Private Consumption in the USSR: Changes in the Assortment of Goods 1940-1959," Soviet Studies, Vol. 13 No. 3, pp. 237-54.

Rybitskii, V. (1961), "Metodicheskoe rukovodstvo dlia ekskursovodov: Razdel pokaza inter'ery," TsAGM 21/1/123, pp. 22-25.

Schwartz, D. (Ed.) (1982), Resolutions and Decisions of the Communist Party of the Soviet Union, Vol. 5: The Brezhnev Years 1964-1981, University of Toronto Press, Toronto. 
Shapiro, J. (1980), "Soviet Consumer Policy in the 1970s: Plan and Performance," in Kelley, D.R. (Ed.), Soviet Politics in the Brezhnev Era, Praeger Publishers, New York, NY, pp. 104-128.

Sharov, I., Poliachek, G. (1960), Vkus nado vospytyvat', Novosibirsk, Novosibirskoe knizhnoe izdatel'stvo, Novosibirsk.

Shlapentokh, V. (1989), Public and Private Life of the Soviet People: Changing Values in Post-Stalin Russia, Oxford University Press, Oxford.

Siegelbaum, L. (2008), Cars for Comrades: The Life of the Soviet Automobile, Cornell University Press, Ithaca, NY.

Skovoroda, K. (1960), "Zadachi dal'neishego uluchsheniia torgovogo obsluzhivaniia naseleniia," Planovoe khoziaistvo, No. 2, pp. 43-53.

Skurski, R. (1983), Soviet Marketing and Economic Development, Macmillan, London, pp. 5-6.

Slater, D. (1997), Consumer Culture and Modernity, Polity Press, Cambridge.

Smith, H. (1976), The Russians, London, Sphere Books.

Steiner, A. (1998), "Dissolution of the "Dictatorship of Needs"? Consumer Behaviour and Economic Reform in East Germany in the 1960s," in Strasser, S., McGovern, C., and Judt M. (Eds), Getting and Spending: European and American Consumer Societies in the Twentieth Century, Cambridge University Press, Cambridge, pp. 167-85.

Struev, A. (1964), “Torgovlia i proizvodstvo," Kommunist, No. 16, pp. 39-48.

Trentmann, F. (2004), "Beyond Consumerism: New Historical Perspectives on Consumption," Journal of Contemporary History, Vol. 39 No. 3, pp. 373-401.

USSR Council of Ministers (1959), "O prodazhe rabochim i sluzhashchim v kredit tovarov dlitel'nogo pol'zovaniia," 12 August 1959, in Sobranie postanovlenii pravitel'stva SSSR (Gosiurizdat, Moscow), article 130, pp. 439-40.

Veenis, M. (1997), "Fantastic Things," in Pearce, S.M. (Ed.), Experiencing Material Culture in the Western World, Leicester University Press, London, pp. 154-74.

Verdery, K. (1996), What Was Socialism and What Comes Next? Princeton University Press, Princeton, NJ.

Voeikova, I. (1962), “Vasha kvartira," Rabotnitsa, No. 9, p. 30.

Zavisca, J. (2005), "Consumer Inequalities and Regime Legitimacy in Late Soviet and Post-Soviet Russia," PhD diss., University of California, Berkeley, 2005).

\section{Archives}

GARF (State Archive of the Russian Federation) 9547/1/1311 (Vsesoiuznoe obshchestvo "Znanie").

RGAE/RGANTD (Russian State Archive of the Economy fonds, Russian State Archive of Science and Technology, Samara), 375/1/6, and 375/ 1/13 (VNIIKS, 1966).

RGALI (Russian State Archive of Literature and Art) 2329/4/139 (visitors' books for exhibition Iskusstvo - $v$ byt!, 1961).

TsAGM (Central Moscow City Archive) 21/1/125-130.

TsGALI SpB (Central State Archive of Literature and Art St Petersburg) 341/1/526 (Discussion of models of interiors of small-scale flats in the Leningrad Section of the USSR Architects' Union, 1957). 
1

2

3

4

5

6

7

8

9

10

11

12

13

14

15

16

17

18

19

20

21

22

23

24

25

26

27

28

29

30

31

32

33

34

35

36

37

38

39

40

41

42

43

44

45

46

47

48

49

50

51

52

53

54

55

56

57

58

59

60

1. Unless otherwise attributed, quotations are taken from my interview project Everyday Aesthetics in the Modern Soviet Flat. Translations are my own. 


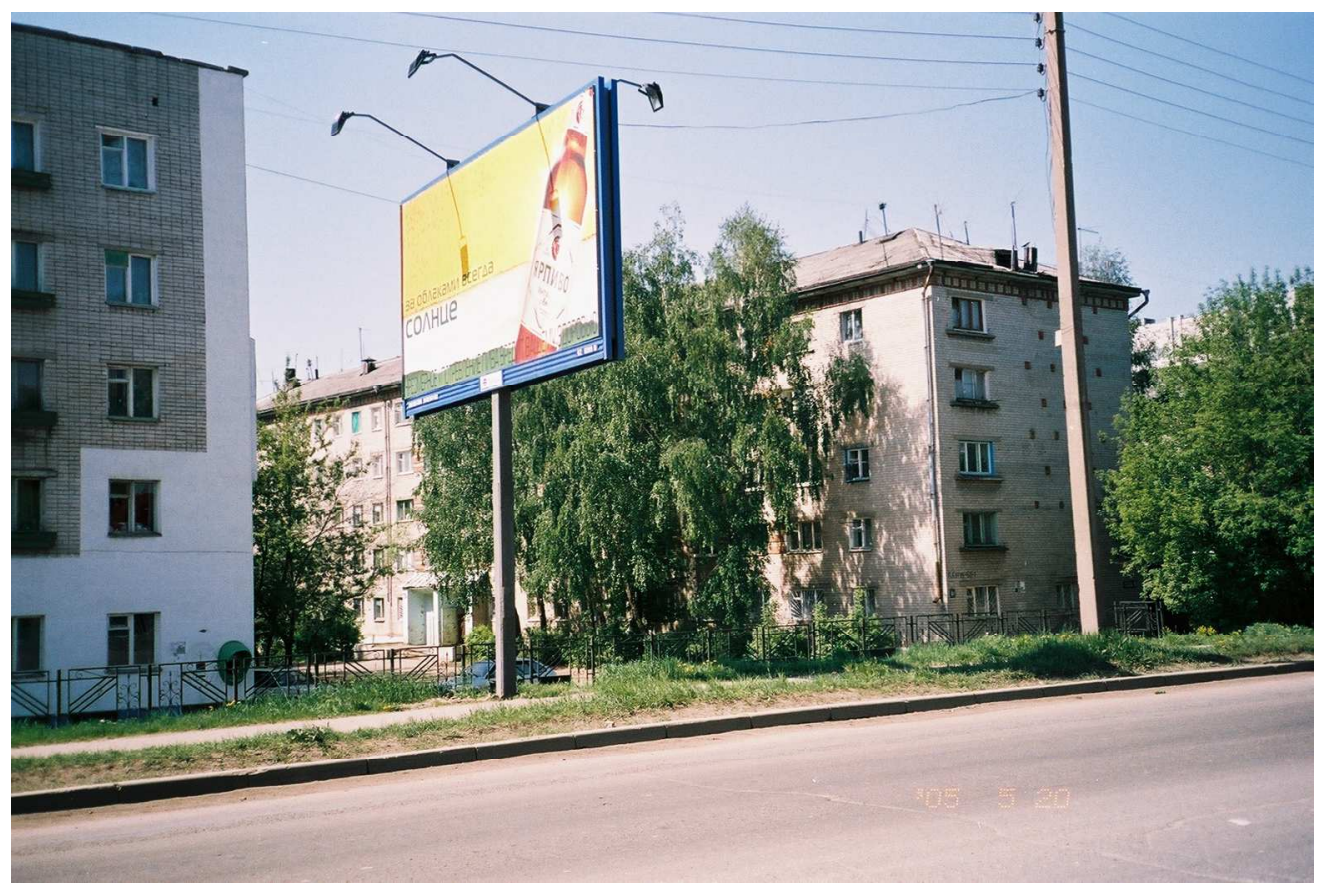

"Khrushchevka" apartment block in Kazan' (Everyday Aesthetics, c. Susan E. Reid) $649 \times 434 \mathrm{~mm}(72 \times 72 \mathrm{DPI})$ 


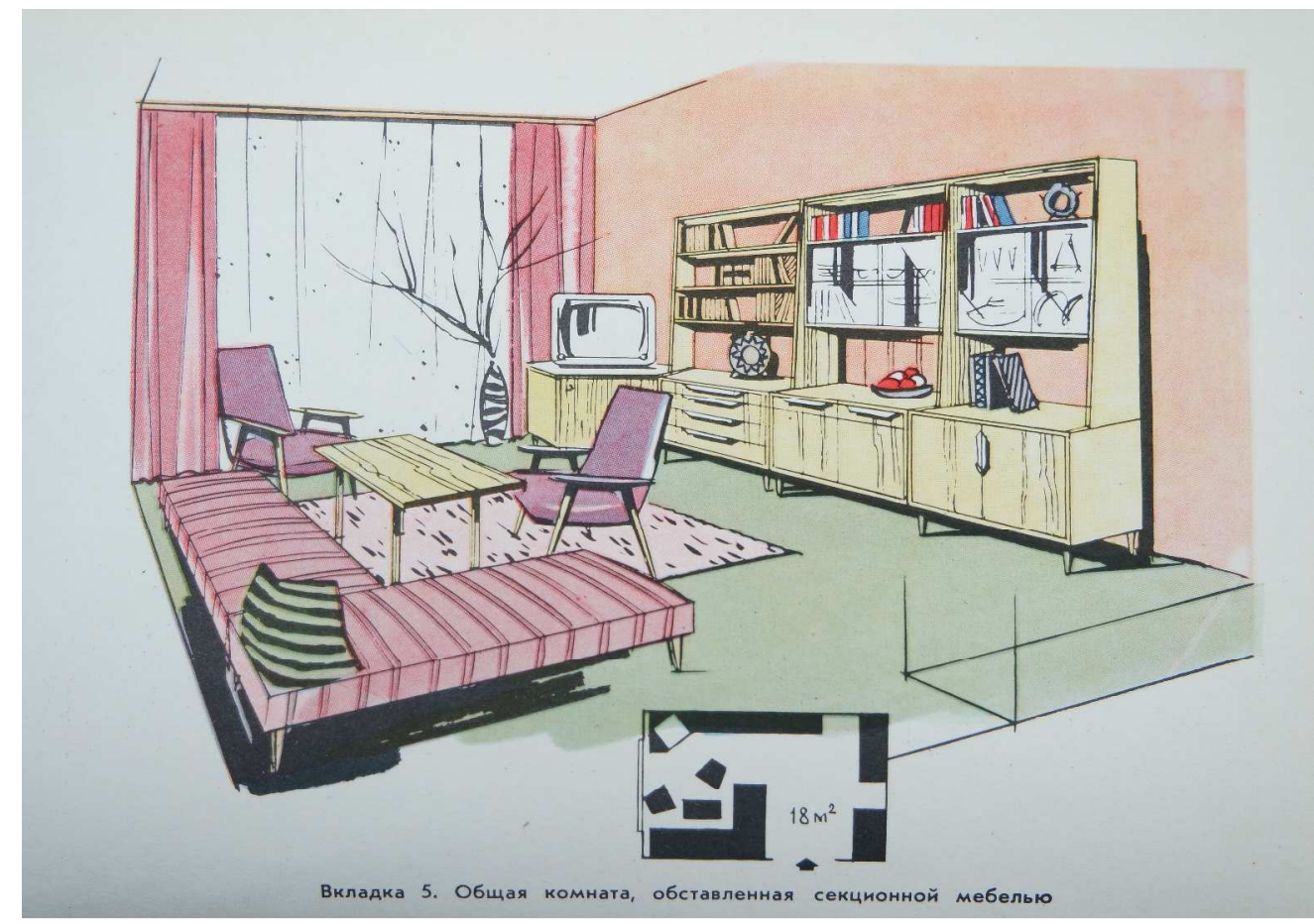

"Contemporary style" interior (Nikol'skaia and Nikol'skii, 1963) $1780 \times 1255 \mathrm{~mm}(72 \times 72 \mathrm{DPI})$ 


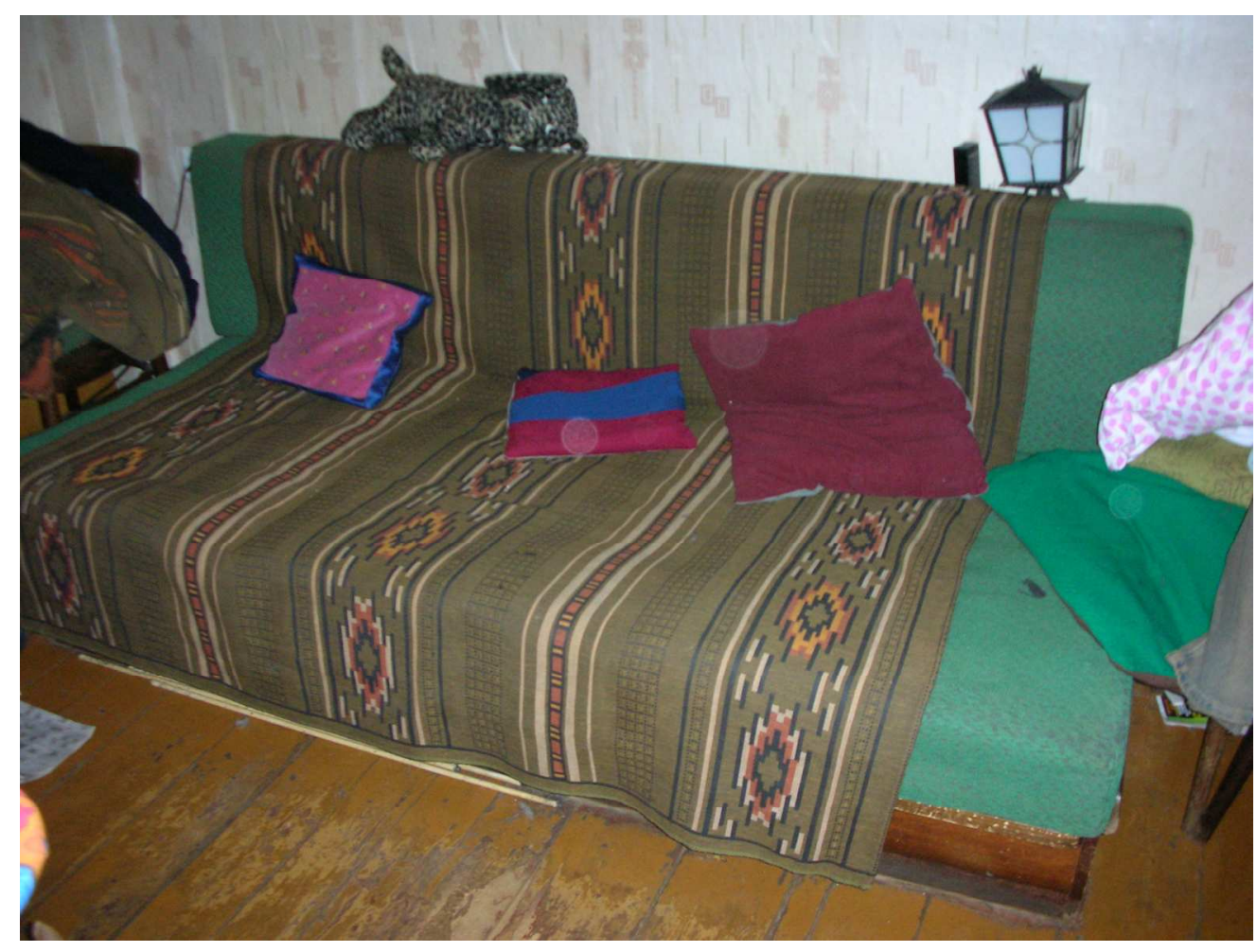

Mariia's "divan" bed-settee (Everyday Aesthetics, c. Susan E. Reid) $219 \times 164 \mathrm{~mm}(300 \times 300 \mathrm{DPI})$ 